Available Online at http://www.bioline.org.br/ja
J. Appl. Sci. Environ. Mgt. 2004

Vol. 8 (1) 71 - 78

\title{
Removal of Oil Spills from Salt Water by Magnesium, Calcium Carbonates and Oxides
}

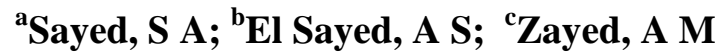 \\ ${ }^{a}$ Dept. of Chemistry, Faculty of Science, Helwan University, Ain Helwan, P.No.11795, Cairo, Egypt. \\ ${ }^{b}$ Research Center, Misr Petroleum Company, Ghamra, Cairo, Egypt. \\ ${ }^{c}$ Egyptian General Petroleum Corporation, Quality Control Dept., New Maadi, P.No. 11742, Cairo, Egypt
}

\begin{abstract}
Magnesium, calcium carbonates and oxides that are widely used in cement industries were employed in studying sorption of petroleum oil spills from salt water at different condition parameters such as temperature, loading weight, degree of salinity. Treatment of magnesium, calcium carbonates and oxides by dodecyl benzene sulphonic acid alcohol was studied to enhance the sorption efficiency. Results obtained showed that treated $\mathrm{MgCO}_{3}, \mathrm{CaCO}_{3}, \mathrm{MgO}$ and $\mathrm{CaO}$ with dodecyl benzene sulphonic can sorb oil by $0.95,1.25,78,0.56$ times its weight respectively; untreated materials can sorb oil by $0.49,0.76,0.44,0.32$ its weight. Characteristics of crude oil and the used materials were investigated by FTIR, X - Ray Fluorescence, Inductive Coupled Plasma, Pour Point and Thermostatic Water Bath instruments. Determination of the amount of crude oil in water was done by extracting the crude oil in tricholorotrifluoroethane and measuring absorbance by FTIR spectrometer. @JASEM
\end{abstract}

As the Crude oil is a very complex mixture of many different chemicals, consequently the effects of an oil spill on the marine environment is dependent on the exact nature and quantity of the oil spilled, as well as such other factors as the prevailing weather conditions and the ecological characteristics of the affected region (Doerffer, 1992; Roy, 1996). According to the complex nature of oils, they do not behave as the same in the environment. Some constituents are noted for they tendency to vaporize while others clearly prefer to bind to solids; some oil hydrocarbons extremely unreactive while other interacts with light, so they have different toxicological effects on the aquatic life and hence on human being (Rene, 1993). Many researches had been forwarded towards organic sorbents for removing oil spills from the surface of salt water such as, de-oiled petroleum asphalt bottoms (Ralph S. Wilcox, 1979), turkey's feathers, pre-cooked puffed cereals (Emile Arseneault and Hervey Tremblay, 1990), paraffin wax (John Bartha and Gyorgy Cscapo, 1992), ground corn-cobs (Adria Brown; and West Bloomfield, 1992), synthetic polymer (Glenn R. Rink, et al., 1999), peat-moss (Annapolis Valley Peat Moss Co. Ltd., 2001), recycled wool - based non woven material (Maja, et. al., 2003) and other carbon products. Organic sorbents are loose particles and are difficult to collect after they have spread on water. Getting rid of those materials are a real problems for all whom concern to the environment. So, many other researches had been concentrated their efforts to use inorganic sorbents. Clays are the most popular materials, which are used as sorbents for oil spills. Clays such as kaolinite (Tarrasevich, 1986, Sayed et al., 2002), bentonite (Laura Kajita, 1997), smectite (Steven Kemnetz and Charles A. Cody, 1998) have been used. Inorganic sorbents have an advantage over organic sorbents in that they can be re-sued again in many industries (EPA, 1999). A little work had been

*Corresponding author

E-mail: saidanwar11745@yahoo.com done to use metal carbonates and oxides to sorb oil spills from the surface of salt water (Sayed and Zayed, 2002; Sayed et al., 2003). Therefore the aim of this research work is to examine the effectiveness of $\mathrm{MgCO}_{3}, \mathrm{CaCO}_{3}, \mathrm{MgO}$ and $\mathrm{CaO}$ to cleanup oil spills.

\section{EXPERIMENTAL}

Gulf of Suez mixture crude oil is used for the purpose of our study since it represents about $60 \%$ of the mass production of Egyptian crude oil, which, is transferred directly to oil refining companies or for exportation along Suez Canal. It is a mixture of crude oils produced from nearly 33 fields located at the Red Sea area. Analyses figures for the tested crude oil according to the institute of petroleum (IP) test methods are listed in Table (1) (IP, 2001).

Table 1. Physical properties of Gulf Suez mixture crude oil

\begin{tabular}{|c|c|c|}
\hline Test & Test method & Results \\
\hline Density at $15^{\circ} \mathrm{C} \mathrm{Kg} / \mathrm{L}$ & IP 160 & 0.8544 \\
\hline Sediment & IP 53 & NIL \\
\hline \%Volume & IP 74 & 0.35 \\
\hline$\%$ mass & IP 77 & 0.004 \\
\hline$\%$ mass & IP 336 & 1.42 \\
\hline Pour point & IP 15 & -3 \\
\hline $\begin{array}{l}\text { Viscosity Redweed } \\
\text { at } 37.8^{\circ} \mathrm{C} \text { Sec. }\end{array}$ & IP 212 & 31 \\
\hline Iron $\quad \mu \mathrm{g} / \mathrm{ml}$ & & 130 \\
\hline Vanadium & $\begin{array}{r}\text { Inductive } \\
\text { Coupled }\end{array}$ & 70 \\
\hline Chromium $\quad \mu \mathrm{g} / \mathrm{ml}$ & Plasma & 30 \\
\hline
\end{tabular}

I.R spectra (FT/IR-410 Spectrometer, Jasco) of the tested petroleum crude oil were demonstrated in Table (2) and were shown in our earlier publication as Fig 1 (Sayed et al 2003) and is not shown here for brevity. Inspection of these spectra reveals the 
presence of the following two peaks at wave no. $2923 \mathrm{~cm}^{-1}$ and $2853 \mathrm{~cm}^{-1}$ represent $-\mathrm{CH}_{3}$ and $-\mathrm{CH}_{2}-$ stretching frequencies; two peaks at wave no $1462 \mathrm{~cm}^{-1}$ and $1377 \mathrm{~cm}^{-1}$ represent $-\mathrm{CH} 3$ and $-\mathrm{CH}_{2}-$ bending frequencies and peak at $722 \mathrm{~cm}^{-1}$ for aliphatic hydrocarbons of chains containing carbon atoms equal or greater than seven. These data indicate that the crude oil has a paraffinic nature (Silverstein, et al., 1991.; Wauquier, 1995).

Fig.1. Infra Red spectra (FT/IR-410 Spectrometer, Jasco) of the tested crude oil.

Table 2. Infra Red signals and assignments of the crude oil.

\begin{tabular}{ll}
\hline Wave number $\left(\mathrm{cm}^{-1}\right)$ & $\begin{array}{l}\text { Assignment of chemical } \\
\text { groups }\end{array}$ \\
\hline 2923 & $-\mathrm{CH}_{3}$ stretching \\
2853 & $-\mathrm{CH}_{2}$ - stretching \\
1462 & $-\mathrm{CH}_{3}$ bending \\
1377 & $-\mathrm{CH}_{2}$ - bending \\
722 & $\begin{array}{l}\text { Aliphatic hydrocarbons of } \\
\text { chains containing carbon } \\
\\
\text { atoms } \geq 7\end{array}$ \\
\hline
\end{tabular}

Determination of petroleum hydrocarbons in water was done using the American society for testing and materials ASTM D-3921, 2002. A calibration curve for determining the amount of oil on the surface of saline water was constructing by following these steps. Prepare a stock solution of crude oil by rapidly transferring $1 \mathrm{ml}$ of the crude oil to a tared $100 \mathrm{ml}$ volumetric flask. Stopper flask and weigh to nearest milligram. Add 1,1,2 tricholoro-1,2,2 trifluoroethane solvent to dissolve and dilute to mark. Using volumetric techniques, prepare a series of standards. Select a pair of matched near-infrared silica cells. A 1-cm-path-lenghth cell is appropriate. Scan standards and samples from $3200 \mathrm{~cm}^{-1}$ to $2700 \mathrm{~cm}^{-1}$ with solvent in reference beam and record results on absorbance paper. Measure absorbances of samples and standards by constructing a straight base line over the scan range. And measuring absorbance of the maximum peak at $2930 \mathrm{~cm}^{-1}$ and subtracting base line absorbance at that point. Use scans of standards to prepare a calibration curve as in Figure (2).

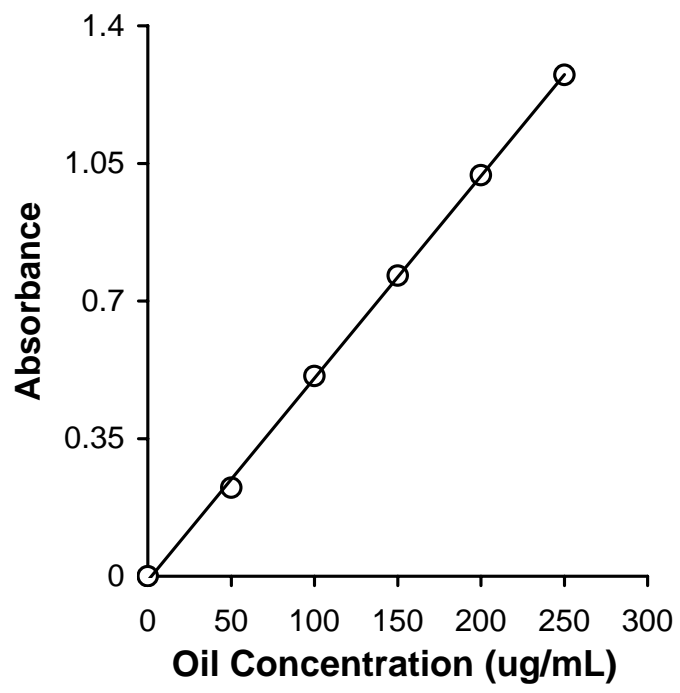

Fig. 2. Calibration curve of the tested crude oil.
Procedure of determination was done by transferring the water sample to a separatory funnel coated with silicone oil, and extracting the petroleum crude oil by shaking the water sample with $30 \mathrm{ml} 1,1,2$ tricholoro-1,2,2 trifluoroethane solvent. Drain the solvent from bottom. Shake the water sample with another $30 \mathrm{ml}$ of the solvent. Repeat with a final 30 $\mathrm{ml}$ of the solvent. Transfer extracts to $100 \mathrm{ml}$ volumetric flask and dilute to the mark. Measure the absorbance. Measure the volume of extracted water. Calculate the concentration of the crude oil in water according to the following equation:

$$
\mathrm{C}=\frac{R x D}{V}
$$

Where,

$\mathrm{C}=$ Concentration of crude oil, $\mathrm{mg} / \mathrm{L}$.

$\mathrm{R}=$ Amount of crude oil in $100 \mathrm{ml}$ of untreated extract, mg.

$\mathrm{V}=$ Volume of extracted water.

$\mathrm{D}=$ Dilution factor;

$$
\mathrm{D}=\frac{V_{d}}{V_{a}}
$$

$\mathrm{V}_{\mathrm{d}}=$ Volume of diluted extracted water; $\mathrm{V}_{\mathrm{a}}=$ Volume of undiluted extracted water.

The uptake efficiency of the petroleum crude oil on $\mathrm{MgCO}_{3}, \mathrm{CaCO}_{3}, \mathrm{MgO}$ and $\mathrm{CaO}$ was calculated according to the equation:

Uptake efficiency $\%=\frac{C_{o}-C_{w}}{C_{w}} \times 100$

Where,

$\mathrm{W}_{\mathrm{o}}$ is the initial concentration and $\mathrm{W}_{\mathrm{w}}$ is the final concentration.

The adsorption isotherm in dilute solution is formulated by Freundlich (Kin H. Tan, 1998) as: 


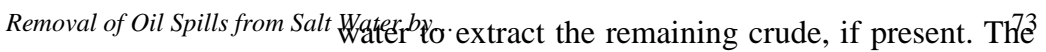

$$
\mathrm{C}_{\mathrm{s}}=K C_{w}^{n}
$$

Where $\mathrm{C}_{\mathrm{s}}$ is the amount of oil retained by unit mass of sorbent

$\mathrm{C}_{\mathrm{w}}$; the amount of oil in water

$\mathrm{K}$, n; constants

Another version of Freundlich is

$$
\mathrm{K}_{\mathrm{d}}=\frac{C_{s}}{C_{w}}
$$

Where, the distribution ratio $\left(\mathrm{K}_{\mathrm{d}}\right)$ describes the portioning of the oil between adsorbent and liquid phases. Strongly adsorbed oil exhibits high $\mathrm{K}_{\mathrm{d}}$ values. The $K_{d}$ is also affected by temperature, degree of salinity, material weight, and concentration of some cations and anions that are commonly present in water.

\section{PROCEDURE OF TREATMENT}

A sample of $0.6 \mathrm{~g}$ of crude oil was added to a $1 \mathrm{~L}$ Beaker containing $750 \mathrm{~mL}$ saline water at. The Beaker walls were coated formally, with silicone oil to prevent crude oil from sticking to the walls. The Beaker content was shaken using a thermostatic water bath at different condition parameters of degree of salinity, temperature, sorbing time and sorbent weight to simulate sea waves. A weighed sample of the used materials was spread over the surface of water to sorb crude oil from the surface, where substantial amounts of crude were seen to sink. A fixed volume of 1,1,2 tricholoro-1,2,2 trifluoroethane was carefully added to the surface of solvent 1,1,2 tricholoro-1,2,2 trifluoroethane layer was subsequently siphoned off the water surface and subjected to quantitative analysis.

\section{RESULTS AND DISCUSSION}

The uptake efficiency percent of magnesium, calcium carbonates and oxides to remove oil spills from the surface of saline water was studied at various condition parameters of contacting time, loading weight, degree of salinity, temperature, temporary and permanent hardness. Also, the used materials were studied after soaking in dodecyl benzene sulphonic acid. The effect of the contacting time on sorption of oil spill was studied by contacting $0.6 \mathrm{~g}$ crude oil on a saline solution; $750 \mathrm{ml}$ of $0.5 \mathrm{M} \mathrm{NaCl}$ at $30^{\circ} \mathrm{C}$ with $2 \mathrm{~g}$ of $\mathrm{MgCO}_{3}$ or $\mathrm{CaCO}_{3}$ or $\mathrm{MgO}$ or $\mathrm{CaO}$ of particle size less than $63 \mu \mathrm{m}$ for different contacting times. Fig. 3 shows that uptake efficiency percent of the used materials increases as contacting time increases till it reaches a maximum value 79, 92, 89,71\% for $\mathrm{MgCO}_{3}, \mathrm{CaCO}_{3}, \mathrm{MgO}$ and $\mathrm{CaO}$ respectively at 7 minutes. The effect of loading weight on sorption of oil spill was studied by contacting 0.6 g crude oil on a saline solution; $750 \mathrm{ml}$ of $0.5 \mathrm{M} \mathrm{NaCl}$ at $30^{\circ} \mathrm{C}$ with different weights of $\mathrm{MgCO}_{3}, \mathrm{CaCO}_{3}, \mathrm{MgO}$ and $\mathrm{CaO}$ of particle size less than $63 \mu \mathrm{m}$ for 7 minutes. Fig. 4 shows that as the loading weight increases, the uptake efficient percent increases till it reaches maximum value of 79, 92, 89, $71 \%$ for $\mathrm{MgCO}_{3}, \mathrm{CaCO}_{3}, \mathrm{MgO}$ and $\mathrm{CaO}$ at 1.6, 1.2, 2, $2.4 \mathrm{~g}$ of each respectively. This due to the surface area increase as the weight increases.

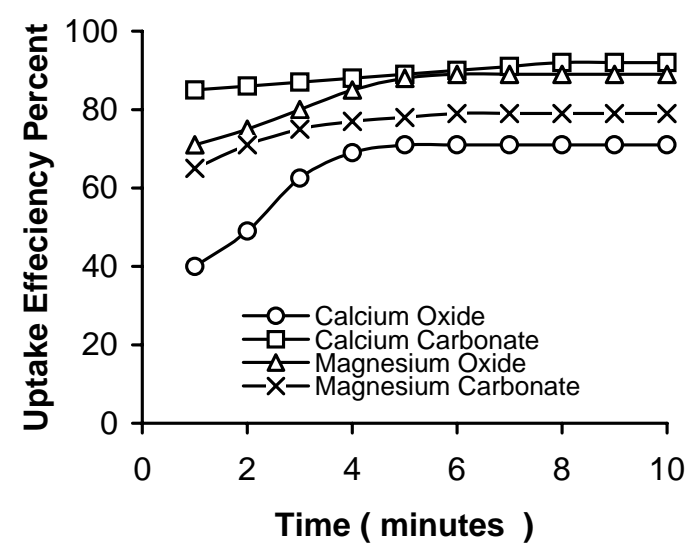

Fig.3. Effect of contacting time on the uptake efficiency percent of $\mathrm{MgCO}_{3}, \mathrm{CaCO}_{3}, \mathrm{MgO}$ and $\mathrm{CaO}$ adsorbents at $\quad 0.5 \mathrm{M} \mathrm{NaCl}, 30^{\circ} \mathrm{C}, 0.6 \mathrm{~g}$ crude oil and 1.6, 1.2, 2, $2.4 \mathrm{~g}$ of particle size less than $63 \mu \mathrm{m}$ for each respectively.

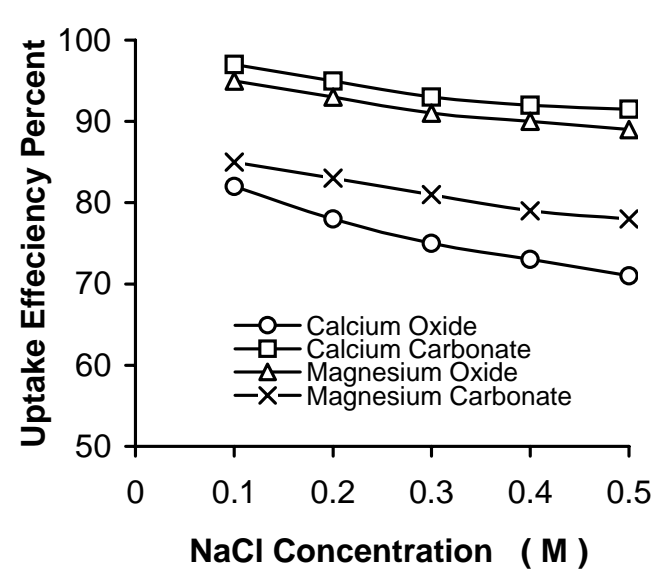

Fig.4. Effect of loading weight on the uptake efficiency percent of $\mathrm{MgCO}_{3}, \mathrm{CaCO}_{3}, \mathrm{MgO}$ and $\mathrm{CaO}$ adsorbents at $\quad 0.5 \mathrm{M} \mathrm{NaCl}, 30^{\circ} \mathrm{C}, 0.6 \mathrm{~g}$ crude oil, 7 minutes and particle size less than 63 $\mu \mathrm{m}$. 
The effect of the degree of salinity on sorption of oil spill was studied by contacting $0.6 \mathrm{~g}$ crude oil on a saline solution; $750 \mathrm{ml}$ of different concentrations of $\mathrm{NaCl}$ at $30^{\circ} \mathrm{C}$ with 1.6, 1.2, 2, $2.4 \mathrm{~g}$ of $\mathrm{MgCO}_{3}$, $\mathrm{CaCO}_{3}, \mathrm{MgO}$ and $\mathrm{CaO}$ of particle size less than 63 $\mu \mathrm{m}$ for 7 minutes. Fig.5 shows that as the concentration of sodium chloride increases, the uptake efficiency percent of the used materials increases till it reaches a value of $79,92,89,71 \%$ for

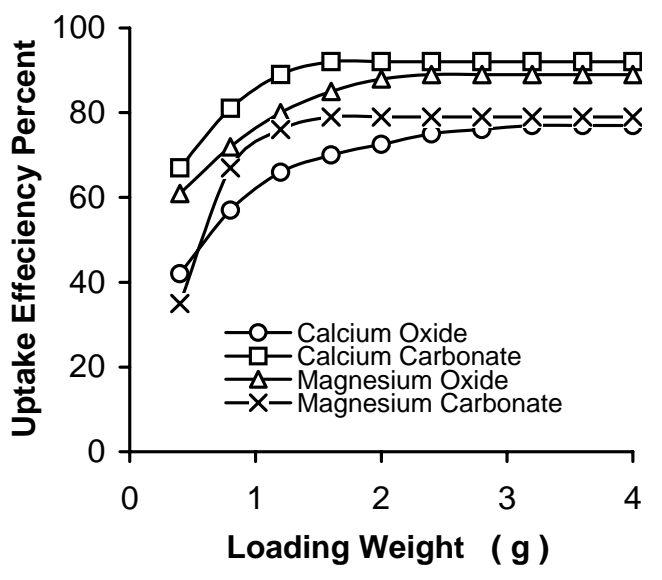

Fig.5. Effect of $\mathrm{NaCl}$ concentration on the uptake efficiency percent of $\mathrm{MgCO}_{3}, \mathrm{CaCO}_{3}, \mathrm{MgO}$ and $\mathrm{CaO}$ adsorbents at $30^{\circ} \mathrm{C}, 0.6$ g crude oil, 7 minutes and 1.6, 1.2, 2, $2.4 \mathrm{~g}$ of particle size less than $63 \mu \mathrm{m}$ for each respectively.

The effect of the temperature sorption of oil spill was studied by contacting $0.6 \mathrm{~g}$ crude oil on a saline solution; $750 \mathrm{ml}$ of $0.5 \mathrm{M} \mathrm{NaCl}$ with $1.6,1.2,2$, $2.4 \mathrm{~g}$ of $\mathrm{MgCO}_{3}, \mathrm{CaCO}_{3}, \mathrm{MgO}$ and $\mathrm{CaO}$ of particle size less than $63 \mu \mathrm{m}$ for 7 minutes at different temperatures. Fig.6 shows that the optimum temperature range of the used materials to adsorb oil spills is $20-40^{\circ} \mathrm{C}$ indicating that the sorption process is an adsorption process and depends on the temperature. The effect of particle size on sorption of oil spill was studied by contacting $0.6 \mathrm{~g}$ crude oil on a saline solution; $750 \mathrm{ml}$ of $0.5 \mathrm{M} \mathrm{NaCl}$ with $1.6,1.2$, 2, $2.4 \mathrm{~g}$ of $\mathrm{MgCO}_{3}, \mathrm{CaCO}_{3}, \mathrm{MgO}$ and $\mathrm{CaO}$ of particle size less than $63 \mu \mathrm{m}$ for 7 minutes at $30^{\circ} \mathrm{C}$. Fig. 7 shows that as the particle size increases the uptake efficiency percent of the used materials decreases till it reaches a value of 79, 92, 89, 71\% for $\mathrm{MgCO}_{3}$, $\mathrm{CaCO}_{3}, \mathrm{MgO}$ and $\mathrm{CaO}$ respectively. This behavior was attributed to the increase of sedimentation rate with the increase in particle size. The effect of temporary hardness; bicarbonate and carbonate anions expressed as sodium bicarbonate and carbonate and permanent hardness; calcium and magnesium cations, expressed as calcium and the adsorbents; $\mathrm{MgCO}_{3}, \mathrm{CaCO}_{3}, \mathrm{MgO}$ and $\mathrm{CaO}$ respectively at which, the maximum concentration is $0.5 \mathrm{M}$, where water is considered to be saline if it at least contains $0.5 \mathrm{M} \mathrm{NaCl}$. This is attributed to the increase of increase the sedimentation rate of $\mathrm{MgCO}_{3}, \mathrm{CaCO}_{3}, \mathrm{MgO}$ and $\mathrm{CaO}$ towards the bottom of water which decreases contacting with the oil spill (Foss and Nilsen, 1996; ASTM D-4920, 2002).

magnesium chloride on sorption of oil spill was studied by contacting $0.6 \mathrm{~g}$ crude oil on a saline water; $750 \mathrm{ml}$ of $0.5 \mathrm{M} \mathrm{NaCl}$ that contains different concentrations of sodium bicarbonate and carbonate, calcium and magnesium chloride at $30^{\circ} \mathrm{C}$ with 1.6 , 1.2, 2, $2.4 \mathrm{~g}$ of $\mathrm{MgCO}_{3}, \mathrm{CaCO}_{3}, \mathrm{MgO}$ and $\mathrm{CaO}$ of particle size less than $63 \mu \mathrm{m}$ for 7 minutes. Figs. (8-11) show that as the concentration of $\mathrm{MgCl}_{2}$, $\mathrm{CaCl}_{2}$ increases the uptake efficiency percent decreases slightly due to the exchange of calcium and magnesium ions with the $\mathrm{MgCO}_{3}, \mathrm{CaCO}_{3}, \mathrm{MgO}$ and $\mathrm{CaO}$ which hinders the adsorption of crude oil molecules and as $\mathrm{NaHCO}_{3}$ and $\mathrm{Na}_{2} \mathrm{CO}_{3}$ increases, the uptake efficiency percent increases slightly. This due to as the concentrations of $\mathrm{NaHCO}_{3}$ and $\mathrm{Na}_{2} \mathrm{CO}_{3}$ increase, the oil spill tends to not spread over a large area that enhance the contact between the oil spill and $\mathrm{MgCO}_{3}, \mathrm{CaCO}_{3}, \mathrm{MgO}$ and $\mathrm{CaO}$ (Singh and Pandey, 1991; EPA, 1999). Distribution ratio $\left(K_{d}\right)$ of the amount of oil retained by unit mass of $\mathrm{MgCO}_{3}$, $\mathrm{CaCO}_{3}, \mathrm{MgO}$ and $\mathrm{CaO}$ to the amount of oil in water was studied by plotting $\mathrm{Cs}$ versus $\mathrm{Cw}$ at optimum conditions of contacting time 7 minute, temperature $30^{\circ} \mathrm{C}, 0.5 \mathrm{M} \mathrm{NaCl}$ and 1.6, 1.2, 2, $2.4 \mathrm{~g}$ of $\mathrm{MgCO}_{3}$, $\mathrm{CaCO}_{3}, \mathrm{MgO}$ and $\mathrm{CaO}$ of particle size less than 63 $\mu \mathrm{m}$ respectively, as in Fig. 12, where, the slope of the resulting straight line is distribution ratio $\mathrm{K}_{\mathrm{d}}$. It is clear from the Fig.12. that $\mathrm{K}_{\mathrm{d}}$ is $0.49,0.76,0.44,0.32$ for the adsorbents $\mathrm{MgCO}_{3}, \mathrm{CaCO}_{3}, \mathrm{MgO}$ and $\mathrm{CaO}$ respectively. Since strongly adsorbed oil exhibits $\mathrm{K}_{d}$ values. Sorbed phases according to values obtained can be arranged in the following order:

$\mathrm{CaCO} 3>\mathrm{MgCO} 3>\mathrm{MgO}>\mathrm{CaO}$. The effect of treating $\mathrm{MgCO}_{3}, \mathrm{CaCO}_{3}, \mathrm{MgO}$ and $\mathrm{CaO}$ with different concentrations of dodecyl benzene sulphonic acid (where the used materials was soaked in different concentrations of dodecyl benzene sulphonic acid for 24 hours and dried with a dry stream of air), on sorption of oil was studied by contacting $0.6 \mathrm{~g}$ crude oil on a saline solution; $750 \mathrm{ml}$ of $0.5 \mathrm{NaCl}$ at $30^{\circ} \mathrm{C}$ with 1.6, 1.2, 2 and $2.4 \mathrm{~g}$ of the treated $\mathrm{MgCO}_{3}, \mathrm{CaCO}_{3}, \mathrm{MgO}$ and $\mathrm{CaO}$ with dodecyl benzene sulphonic acid for 7 minutes. Fig.13 shows that uptake efficiency percent increases as concentration of dodecyl benzene sulphonic acid increases till it reaches maximum value of about 95, $100,95,80 \%$ for $\mathrm{MgCO}_{3}, \mathrm{CaCO}_{3}, \mathrm{MgO}, \mathrm{CaO}$ at dodecyl benzene sulphonic acid concentrations 60, 
30, 50, $40 \mu \mathrm{g} / \mathrm{ml}$ respectively. The effect of the

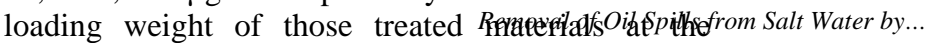

previous conditions is illustrated as in Fig.14; it is clearly seen that as the loading weight increases, the uptake efficient percent increases till it reaches maximum value of $79,92,89,71 \%$ for the treated $\mathrm{MgCO}_{3}, \mathrm{CaCO}_{3}, \mathrm{MgO}, \mathrm{CaO}$ at $1,0.8,1.2,1.4 \mathrm{~g}$ respectively. Distribution ratio $\left(\mathrm{K}_{\mathrm{d}}\right)$ of the amount of oil retained by unit mass of the treated $\mathrm{MgCO}_{3}$, $\mathrm{CaCO}_{3}, \mathrm{MgO}$ and $\mathrm{CaO}$ with dodecyl benzene sulphonic acid to the amount of oil in water was studied by plotting $\mathrm{Cs}$ versus $\mathrm{Cw}$ at optimum conditions of contacting time 7 minute, temperature $30^{\circ} \mathrm{C}$, sodium chloride concentration $0.5 \mathrm{M}$ and $1,0.8,1.2,1.4 \mathrm{~g}$ of the treated $\mathrm{MgCO}_{3}, \mathrm{CaCO}_{3}, \mathrm{MgO}$, $\mathrm{CaO}$ respectively, as in Fig. 15, where, the slope of the resulting straight line is $\mathrm{K}_{\mathrm{d}}$. It is clear from the Fig.15. that $\mathrm{K}_{\mathrm{d}}$ is $0.95,1.25,0.78,0.56$ for $\mathrm{MgCO}_{3}$, $\mathrm{CaCO}_{3}, \mathrm{MgO}$ and $\mathrm{CaO}$ respectively. Comparing those values of the $\mathrm{K}_{\mathrm{d}}$ with that of the untreated forms, one can predict that the treating process raises the uptake efficiency twice more. Adsorbed crude oil can be stripped from the used materials by naphtha (a petroleum product of boiling range $30-165^{\circ} \mathrm{C}$ ) or kerosene (a petroleum product of boiling range 150$220^{\circ} \mathrm{C}$ ). Kerosene is much cheaper than naphtha. The stripped materials are charged to reuse again. Contaminated naphtha or kerosene is distilled and is returned for further reuse. Figs.(16,17); show that two minutes is sufficient to strip about 87, 55, 80, $60 \%$ from $\mathrm{MgCO}_{3}, \mathrm{CaCO}_{3}, \mathrm{MgO}$ and $\mathrm{CaO}$ respectively, in case of using naphtha as a stripper and 9 minutes is sufficient to strip about 48.5, 47, 50, $46.5 \%$ from $\mathrm{MgCO}_{3}, \mathrm{CaCO}_{3}, \mathrm{MgO}$ and $\mathrm{CaO}$ respectively, in case of using kerosene as a stripper. Figs. $(18,19)$; show that $25 \mathrm{~mL}$ is sufficient to strip about $94,90,92,94$ $\%$ from $\mathrm{MgCO}_{3}, \mathrm{CaCO}_{3}, \mathrm{MgO}$ and $\mathrm{CaO}$ respectively, in case of using naphtha as a stripper and $15 \mathrm{~mL}$ is sufficient to strip about $61,57,63,59 \%$ from $\mathrm{MgCO}_{3}, \mathrm{CaCO}_{3}, \mathrm{MgO}$ and $\mathrm{CaO}$ respectively, in case of using kerosene as a stripper. So, using naphtha as a stripper is much more efficient than kerosene. Also, $\mathrm{MgCO}_{3}, \mathrm{CaCO}_{3}, \mathrm{MgO}$ and $\mathrm{CaO}$ can be reused again to adsorb further crude oil or can be charged to the cement factories to be reused in the manufacture of cement.

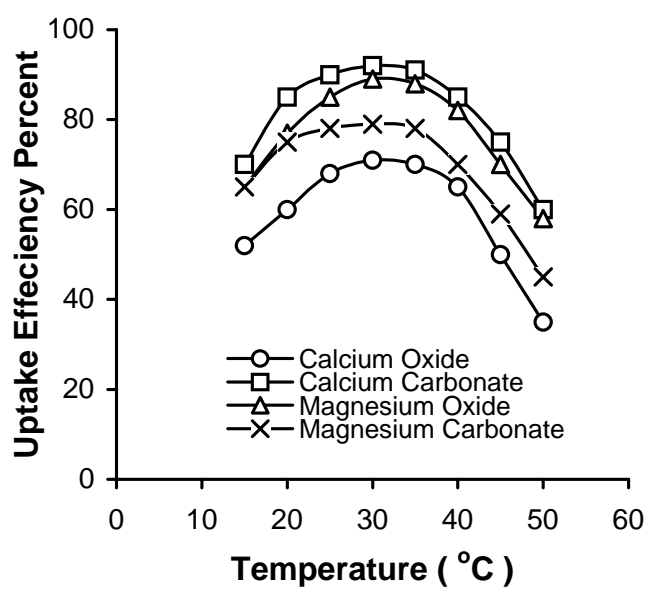

Fig.6. Effect of temperature on the uptake efficiency percent of $\mathrm{MgCO}_{3}, \mathrm{CaCO}_{3}, \mathrm{MgO}$ and $\mathrm{CaO}$ adsorbents at $0.5 \mathrm{M} \mathrm{NaCl}, 0.6 \mathrm{~g}$ crude oil, 7 minutes and 1.6, 1.2, 2 , $2.4 \mathrm{~g}$ of particle size less than $63 \mu \mathrm{m}$ for each respectively.
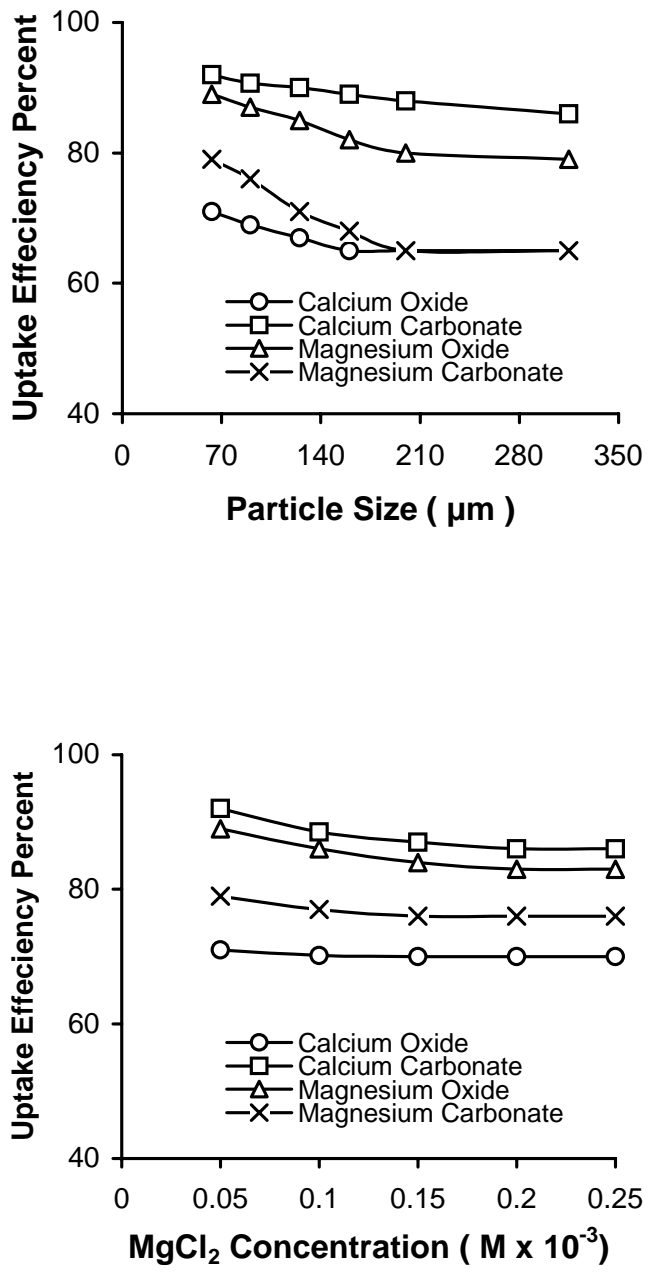

Fig.7. Effect of particle size on the uptake efficiency percent of $\mathrm{MgCO}_{3}, \mathrm{CaCO}_{3}, \mathrm{MgO}$ and $\mathrm{CaO}$ adsorbents at 0.5 $\mathrm{M} \mathrm{NaCl}, 30^{\circ} \mathrm{C}, 0.6 \mathrm{~g}$ crude oil, 7 minutes and $1.6,1.2,2,2.4$ $\mathrm{g}$ of different particle size for each respectively

Fig.8. Effect of magnesium chloride concentration on the uptake efficiency percent of $\mathrm{MgCO}_{3}, \mathrm{CaCO}_{3}, \mathrm{MgO}$ and $\mathrm{CaO}$ adsorbents at $0.5 \mathrm{M} \mathrm{NaCl}, 30^{\circ} \mathrm{C}, 0.6 \mathrm{~g}$ crude oil, 7 minutes and $1.6,1.2,2,2.4 \mathrm{~g}$ of particle size less than $63 \mu \mathrm{m}$ for each respectively. 


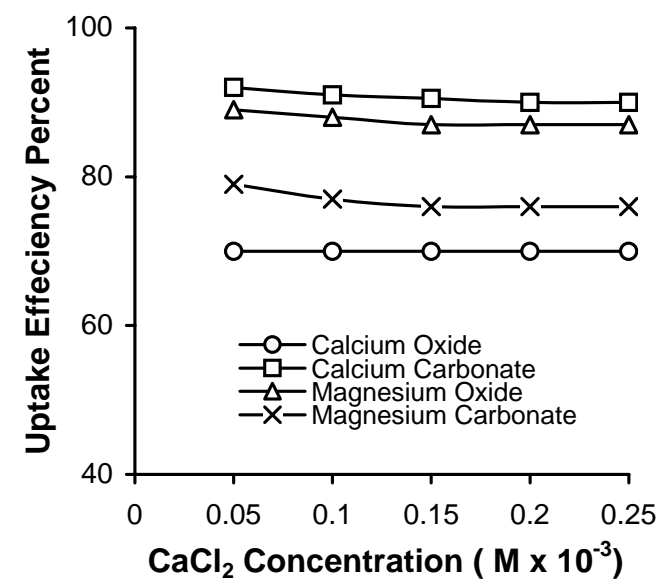

Fig.9. Effect of calcium chloride concentration on the uptake efficiency percent of $\mathrm{MgCO}_{3}, \mathrm{CaCO}_{3}, \mathrm{MgO}$ and $\mathrm{CaO}$ adsorbents at $0.5 \mathrm{M} \mathrm{NaCl}, 30^{\circ} \mathrm{C}, 0.6 \mathrm{~g}$ crude oil, 7 minutes and $1.6,1.2,2,2.4 \mathrm{~g}$ of particle size less than $63{ }^{3} \mu \mathrm{m}$ for each respectively.

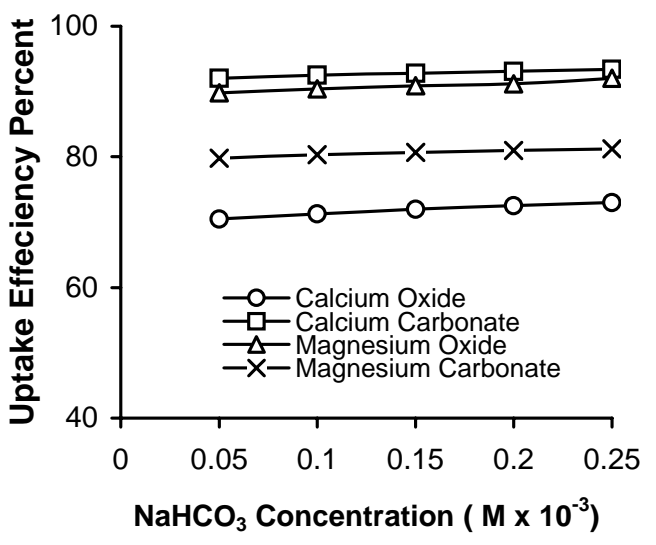

Fig.10. Effect of sodium bicarbonate concentration on the uptake efficiency percent of $\mathrm{MgCO}_{3}, \mathrm{CaCO}_{3}, \mathrm{MgO}$ and $\mathrm{CaO}$ adsorbents at $0.5 \mathrm{M} \mathrm{NaCl}, 30^{\circ} \mathrm{C}, 0.6 \mathrm{~g}$ crude oil, 7 minutes and 1.6, 1.2, 2, $2.4 \mathrm{~g}$ of particle size less than $63 \mu \mathrm{m}$ for each respectively.

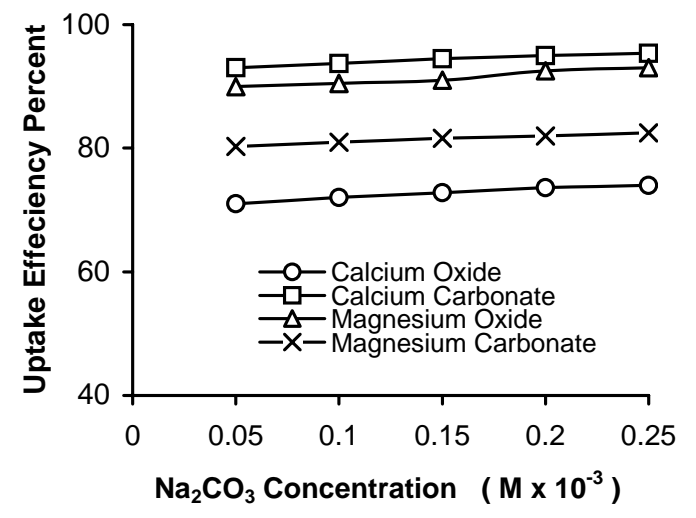

Fig.11. Effect of sodium carbonate concentration on the uptake efficiency percent of $\mathrm{MgCO}_{3}, \mathrm{CaCO}_{3}, \mathrm{MgO}$ and $\mathrm{CaO}$ adsorbents at $0.5 \mathrm{M} \mathrm{NaCl}, 30^{\circ} \mathrm{C}, 0.6 \mathrm{~g}$ crude oil, 7 minutes and 1.6, 1.2, 2, $2.4 \mathrm{~g}$ of $63 \mu \mathrm{m}$ particle size for each respectively.

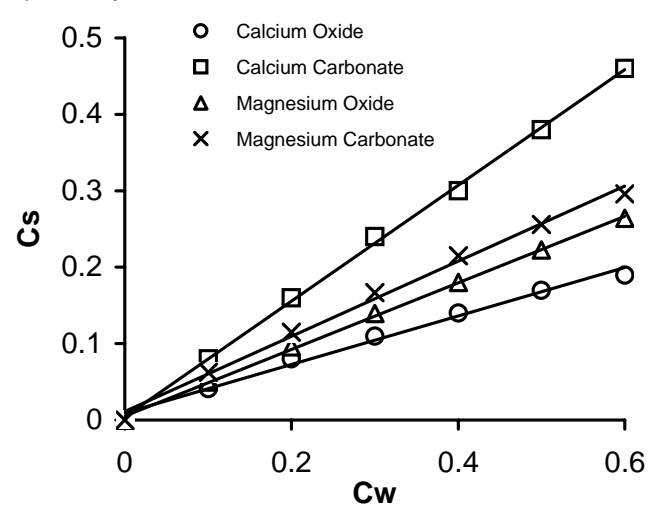

Fig.12. Distribution ratio (Kd) between $\mathrm{MgCO}_{3}, \mathrm{CaCO}_{3}$, $\mathrm{MgO}$ and $\mathrm{CaO}$ adsorbed phases and the saline water at $0.5 \mathrm{M} \mathrm{NaCl}, 30^{\circ} \mathrm{C}, 0.6 \mathrm{~g}$ crude oil and 7 minutes and 1.6, 1.2, $2,2.4 \mathrm{~g}$ of particle size less than $63 \mu \mathrm{m}$ for each respectively. $\quad 76$

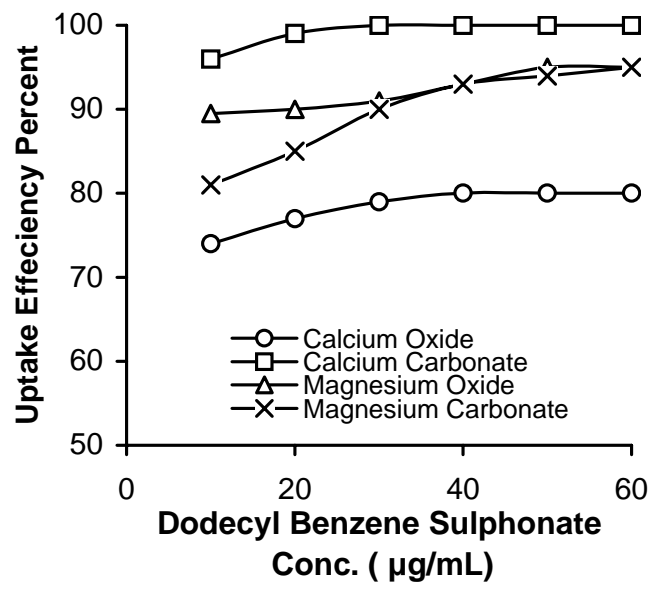

Fig.13. Effect of treating of $\mathrm{MgCO}_{3}, \mathrm{CaCO}_{3}, \mathrm{MgO}$ and $\mathrm{CaO}$ adsorbents with dodecyl benzene sulphonic acid on the uptake efficiency percent at $0.5 \mathrm{M} \mathrm{NaCl}, 0.6 \mathrm{~g}$ crude oil, 7 minutes and 1.6, 1.2, 2, $2.4 \mathrm{~g}$ of particle size less than $63 \mu \mathrm{m}$ for each respectively.

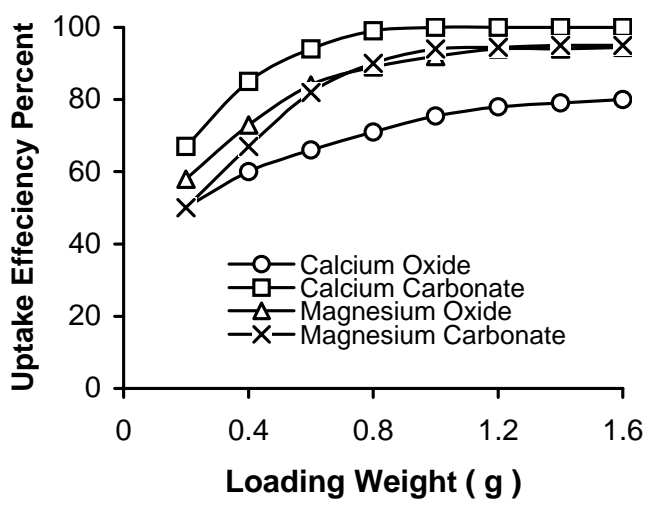

Fig.14. Effect of loading weight on the uptake efficiency percent of the treated $\mathrm{MgCO}_{3}, \mathrm{CaCO}_{3}, \mathrm{MgO}$ and $\mathrm{CaO}$ adsorbents with dodecyl benzene sulphonic acid adsorbents 
at $0.5 \mathrm{M} \mathrm{NaCl}, 30^{\circ} \mathrm{C}, 0.6 \mathrm{~g}$ crude oil, 7 minutes and particle size less than $63 \mu \mathrm{m}$.

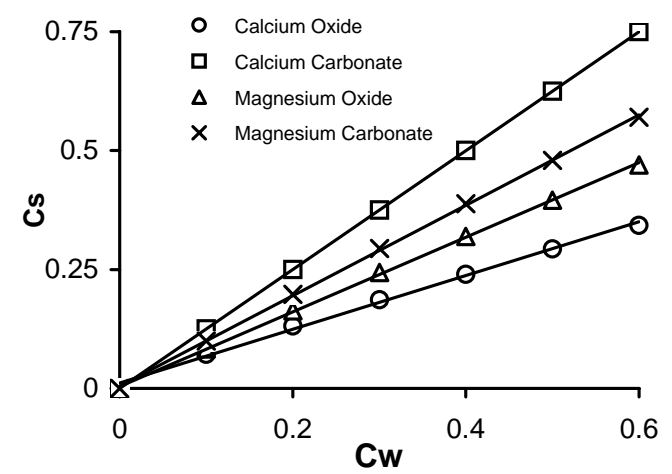

Fig.15. Distribution ratio $(\mathrm{Kd})$ between treated $\mathrm{MgCO}_{3}$, $\mathrm{CaCO}_{3}, \mathrm{MgO}$ and $\mathrm{CaO}$ with dodecyl benzene sulphonic acid adsorbed phases and the saline water at $0.5 \mathrm{M} \mathrm{NaCl}, 30^{\circ} \mathrm{C}$, $0.6 \mathrm{~g}$ crude oil and 7 minutes and 1.4, 0.8, $1.2,1 \mathrm{~g}$ of particle size less than $63 \mu \mathrm{m}$ for each respectively.

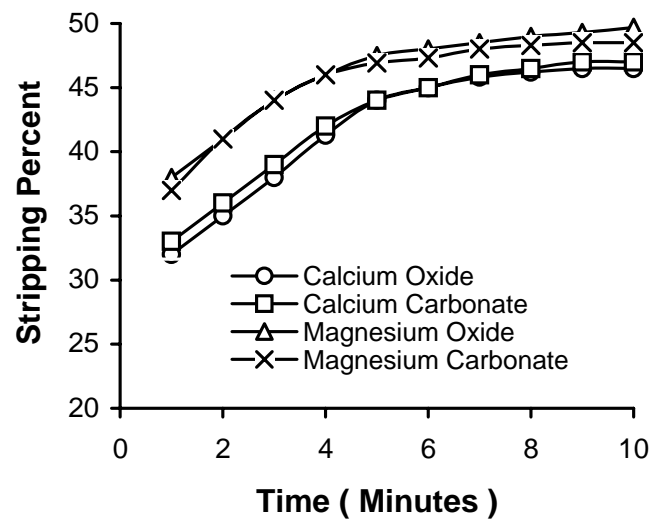

Fig.18. Stripping time of petroleum crude oil from 1.6, 1.2, 2, $2.4 \mathrm{~g}$ of $\mathrm{MgCO}_{3}, \mathrm{CaCO}_{3}, \mathrm{MgO}$ and $\mathrm{CaO}$ by $5 \mathrm{~mL}$ kerosene respectively. Removal of Oil Spills from Salt Water by...

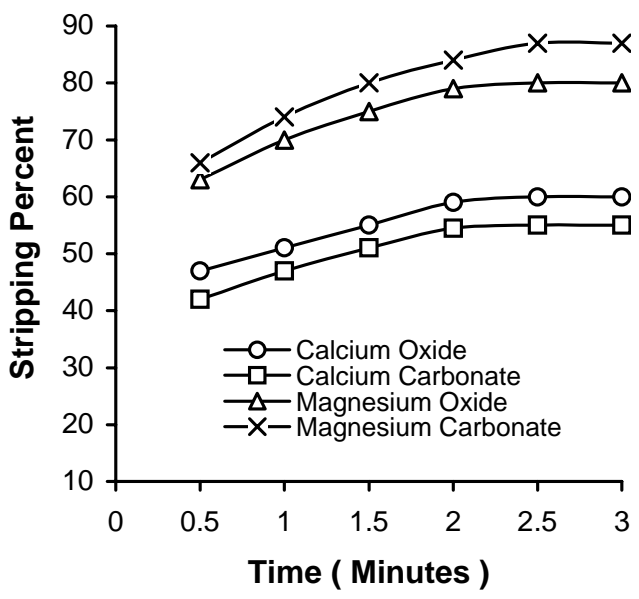

Fig.16. Stripping time of petroleum crude oil from 1.6, 1.2, 2, $2.4 \mathrm{~g}$ of $\mathrm{MgCO}_{3}, \mathrm{CaCO}_{3}, \mathrm{MgO}$ and $\mathrm{CaO}$ by $5 \mathrm{~mL}$ naphtha respectively.

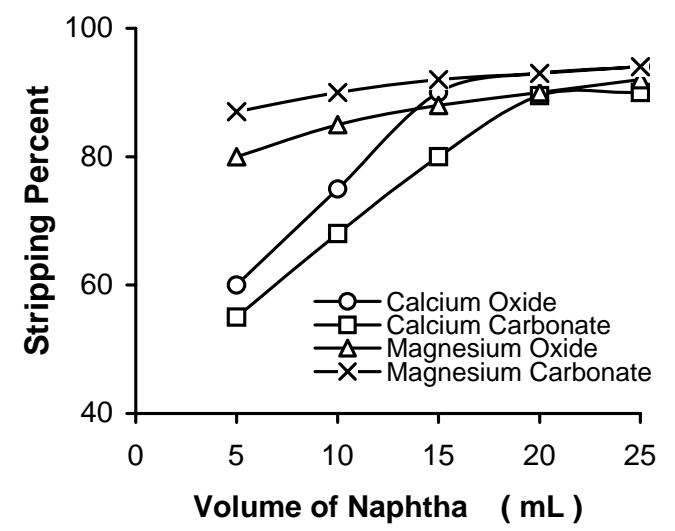

Fig.17. Stripping of petroleum crude oil from 1.6, 1.2, 2, $2.4 \mathrm{~g}$ of $\mathrm{MgCO}_{3}, \mathrm{CaCO}_{3}, \mathrm{MgO}$ and $\mathrm{CaO}$ by kerosene respectively at 9 minutes.

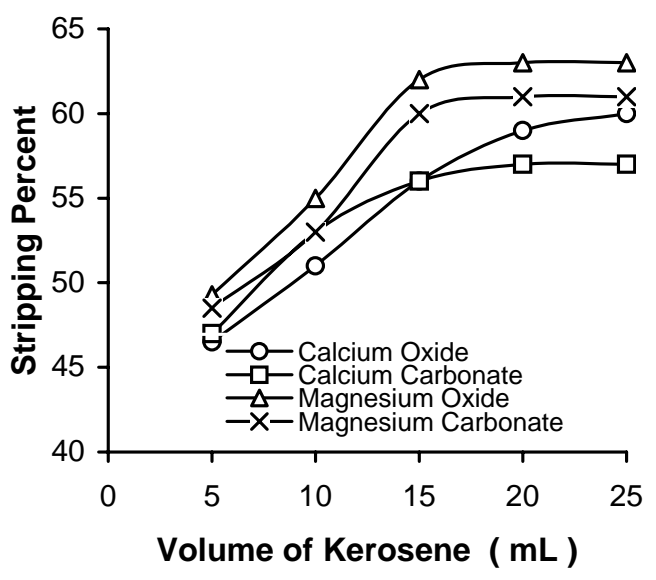

Fig.19. Stripping of petroleum crude oil from 1.6, 1.2, 2 , $2.4 \mathrm{~g}$ of $\mathrm{MgCO}_{3}, \mathrm{CaCO}_{3}, \mathrm{MgO}$ and $\mathrm{CaO}$ by kerosene respectively at 9 minutes.

\section{REFERENCES}

American Society for Testing and Materials, (2002) ASTM D-3921

American Society for Testing and Materials, (2002) ASTM D-4920

Annapolis Valley Peat Moss Co. Ltd., "Cansorb product", Berwick, Nova Scotia, Canada, 2001

Doerffer, J.W., (1992). Oil spill response in the marine environment”, Pergamon Press, Oxford, pp. 391

Environmental Protection Agency (EPA), (1999) Understanding oil spills and oil 
spill response ", Publication 2000 963401, U.S. EPA, Office of Solid Waste and Emergency Response, Dec.

Emile Arseneault and Hervey Tremblay (1990). Use of pre-cooked and puffed cereals as oil spill sorbents ”, U.S. Patent 4,969,774

Foss, S.A., and Nilsen, A.J., (1996) The Modern Coral Reef Aquarium, Vol. 1, Birgit Schmettkamp Verlag, Bornheim, Germany

Glenn R. Rink; Robert L. Rosania; David R. Smith; Thomass C. Johnson; Jan R. Hegeman and Peter A. Allen, (1999) Methods for ameliorating oil spills in marine and inland waters”, U.S. Patent 5, 863, 440

Institute of Petroleum (IP), 2001 Test Methods, Vol. 1, 2

James R. Bragg and Shan H. Yang, (1995) Clay oil flocculation and its role in natural cleaning in Prince William Sound following the Exxon Valdez oil spill Special Technical Publication, N 1219, ASTM, U.S.A.

John Bartha and Gyorgy Csapo, (1992) Method of cleaning up petroleum oil soils”, U.S. Patent 5, 112, 495

Kin H. Tan (1998) Principles of soil chemistry, $2^{\text {nd }}$ Edition, Marcel Dekker Inc.

Laura Kajita (1997) Method and composition for clarifying wastewater", U.S. Patent 5, 670, 435

Maja, M.R.; Dragen, M.J.; Petar, M.J.; Zoran, P.L., and Helga, T.F., (2003) Recycled wool - based non woven material as an oil sorbent”, Environmental Science and Technology, 37 ( 5) 1008 - 1012

Ralph S. Wilcox, (1979). Method for separating oils from water, U.S. Patent 4,160,729,

Rene P. Schwarzenbach, Philip M. Gschwnd, Dieter M. Imbden (1993). Environmental organic chemistry, John Wiley and Sons, Inc., U.S.A.,

Roy M. Harrison, (1996). Pollution causes, effects and control, Third Edition, Royal Society of Chemistry, U.K.
Sayed, S.A.; El Sayed, A.S.; El Kareish, S.M., and Zayed, A.M (2003). Treatment of liquid oil spill by untreated and treated Aswanly clay from Egyp, J. Appl Sci Environ Mgt, 7 (1) 23-33

Sayed, S.A., and Zayed, A.M., (2003). A Study on Using Some Local clay in Treatment of Liquid Oil Spill”, $1^{\text {st }}$ Int. Conf. On New Trends in Chemistry and Their Applications, Cairo Univ., Beni Suef, Egypt, Feb. 2 - 4

Silverstein, R.M.; Clayton Bassler, G. and Terence C. Morrill, (1991). Spectrometric identification of organic compounds", Jone Wiley \& Sons, London, Inc.

Singh, B.P.; Pandey, B.P., (1991). Physical characteristics of natural films formed at a crude oil-water interfaces. Indian Journal of Technology, 29. $443-447$

Steven Kemnetz and Charles A. (1998). Cody, "Composition of matter useful as an oil spill flocculating agent”, U.S. Patent 5, 725, 805

Tarrasevich, Yui.; Verlinskaya, R.M.; Nesterova, M.P.; and Gorniskii, A.B., (1986) Production and properties of modified puffed perlites for removal of petroleum from waste surfaces, Sov. - J. Water Chem. Technol, 8, 6, 34 -39,

Tsukamoto; Tatsuo; Kakio; Kaazuhiko, 1998 Manufacture of ferric sulfate solution as coagulant in waste water treatment, Taki Chemical Co Ltd, Japan

wauquier, J.P., 1995. Petroleum refining series”, Vol. 1, Editions Technip, Paris, France . 
